ISSN : 2615-1995, E-ISSN : 2615-0654

J. Madani., Vol. 4, No. 2, September 2021 (133 - 145)

(C)2018 Lembaga Kajian Demokrasi

https://doi.org/10.33753/madani.v4i2.172

\title{
Uang Elektronik: Praktik dan Substansi Dari Perspektif Keuangan Syariah (Studi Kasus BCA Flazz \& Go-Pay)
}

\author{
Adi Martono \\ Fakultas Ekonomi dan Bisnis, Universitas Pamulang \\ dosen01599@unpam.ac.id \\ Yuddy Yudawirawan \\ Fakultas Ekonomi dan Bisnis, Universitas Pamulang \\ yudayuddy@gmail.com
}

\begin{abstract}
Abstrak
Penggunaan uang elektronik sebagai alat transaksi dalam kehidupan sehari-hari adalah suatu keniscayaan, masyarakat menggunakan uang tersebutuntuk membayar berbagai keperluan seperti membeli barang di marketplace, membeli makanan secara online, tiket kereta api KRL, membayar tiket tol dan lain-lain. Di sisi lain, penggunaan uang elektronik di masyarakat menimbulkan pertanyaan terutama bagi umat Islam. Apakah uang elektronik sebagai alat tukar sesuai dengan Al-Qur'an dan As-Sunnah? Beberapa cendekiawan muslim Indonesia yang concern terhadap praktik Muamalah Maaliyah telah memberikan pemikiran dan pendapatnya tentang penggunaan uang elektronik. Tulisan ini merupakan langkah dalam menjawab pertanyaan tersebut. Tulisan ini akan mencoba memberikan penjelasan mengapa penggunaan uang elektronik tidak sesuai dengan Al-Qur'an dan As-Sunnah. Penelitian ini menggunakan studi kasus - penelitian kualitatif sebagai metodologi penelitian. Untuk penelitian ini data dikumpulkan dari dokumentasi: ketentuan Bank Indonesia, fatwa Dewan Syariah-Majelis Ulama Indonesia (DSN-MUI), fatwa ulama sedunia, instruksi penggunaan uang elektronik dari bank/perusahaan penerbit, observasi dan observasi partisipan yaitu sebagai pengguna uang elektronik yang juga berpengalamanan sebagai bankir di bank milik pemerintah. Dengan menggunakan metode ini, penelitian ini akan mengeksplorasi dan menjelaskan bagaimana uang elektronik dikelola dan mengapa sebagian umat Islam meragukan uang ini. Kesimpulan daripenelitian ini adalah Bank Indonesia selaku regulator dan DSN-MUI yang mengeluarkan fatwa dan ini sejalan dengan fatwa yang dikeluarkan oleh Majma'al-Fiqh al-Islami di bawah Liga Muslim Dunia dalam keputusannya No. 86, 3/9 menerangkan bahwa "simpanan bank, baik di bank Islam maupun bank konvensional, dari sudut pandang fiqih merupakan hutang, memiliki pandangan yang berbeda mengenai konsep dan karakteristik uang elektronik yang digunakan di Indonesia. Solusi dari permasalahan ini adalah Bank Indonesia sebagai regulator perlu membuka ruang agar uang elektronik yang sesuai dengan ketentuan syariah dapat diwujudkan sehingga kepentingan masyarakat muslimin terpenuhi.
\end{abstract}

Kata Kunci : uang elektronik, bank, penerbit uang elektronik, riba

\begin{abstract}
The use of electronic money as a transaction tool in everyday life is a necessity, people use the money to pay for various needs such as buying goods in the marketplace, buying food online, KRL train tickets, paying toll tickets and others. On the other hand, the use of electronic money in society raises questions, especially for Muslims. Is electronic money as a medium of
\end{abstract}


exchange in accordance with the Qur'an and As-Sunnah? Several Indonesian Muslim scholars who are concerned about the practice of Muamalah Maaliyah have given their thoughts and opinions on the use of electronic money. This paper is a step in answering this question. This paper will try to provide an explanation why the use of electronic money is not in accordance with the Qur'an and As-Sunnah. This research uses case study - qualitative research as research methodology. For this study, data were collected from documentation: Bank Indonesia regulations, the fatwa of the Sharia Council-Indonesian Ulema Council (DSN-MUI), fatwas of world scholars, instructions for the use of electronic money from banks/issuing companies, participant observations and observations, namely as users of electronic money who also use electronic money. Experienced as a banker in a state-owned bank. Using this method, this research will explore and explain how electronic money is managed and why some Muslims doubt this money. The conclusion of this study is that Bank Indonesia as the regulator and DSN-MUI issued a fatwa and this is in line with the fatwa issued by Majma' al-Fiqh al-Islami under the World Muslim League in its decision No. 86, 3/9 explains that "bank deposits, both in Islamic banks and conventional banks, from the fiqh point of view are debt, having different views on the concept and characteristics of electronic money used in Indonesia. The solution to this problem is that Bank Indonesia as a regulator needs to open space so that electronic money that is in accordance with sharia provisions can be realized so that the interests of the Muslim community are met.

Keywords : Electronic Money, Bank, Electronic Money Issuer, Riba

\section{PENDAHULUAN}

Uang elektronik merupakan revolusi terbesar dari sistem pembayaran yang ada saat, hal ini ditandai sejak pertama kali digunakannya cek kemudian berubah menjadi kartu kredit hingga penggunaan uang elektronik pada saat ini. Perkembangan teknologi saat ini menjadikan uang elektronik sebagai sarana pertukaran yang menyimpan nilai dalam bentuk elektronik di mana uang tersebut sebagai sarana pembayaran yang setara dengan uang tunai tetapi disimpan dalam bentuk digital (Dodgson, Gann, Wladawsky-Berger, Sultan, \& George, 2015). Uang elektronik merupakan uang yang disimpan secara elektronik sebagai alat pembayaran non tunai kepada merchant, tidak termasuk produk Dana Pihak Ketiga serta tidak dijamin oleh Lembaga Penjamin Simpanan (Usman, 2017). Uang ini digunakan secara komersial untuk transaksi pembayaran barang dan jasa dalam lingkungan dunia yang saling terhubung. Pengunaan dan kemajuan teknologi seperti handphone dan komputer telah telah mempercepat perkembangan penggunaan uang elektronik dalam perdagangan.

Keberadaan uang elektronik merubah transaksi ekonomi sehari-hari seperti pembayaran dan transfer yang sebelumnya dilakukan secara fisik menjadi serba digital. Uang elektronik membuat transaksi keuangan menjadi lebih cepat, murah dan tersebar. Hasil survey penggunaan uang elektronik di kota Semarang menunjukkan bahwa uang elektronik memiliki nilai manfaat, memudahkan dan risiko yang terukur (Singgih, 2016). Penggunaan uang elektronik sudah tidak dapat dipisahkan dari kehidupan masyarakat sehari-hari seperti saat hendak berangkat ke kantor dengan menggunakan jasa transportasi online, kereta api, jalan tol hingga ketika ingin membeli sesuatu di MarketPlace seperti Bulalapak, Tokopedia dsb. Penggunaan uang elektronik oleh masyarakat semakin meningkat karena layanan uang elektronik menjadi pendukung bisnis perusahaan semisal transportasi online Grabike dengan Ovo dan Gojek dengan Go-pay (Tazkiyyaturrohmah, 2018). Dari sisi penggunaan uang elektronik juga mempunyai fungsi lain, dipakai sebagai kartu identitas mahasiswa Fakultas Ekonomi dan Bisnis Universitas Diponegoro (Candraditya, 2013). Di sisi lain penerbit uang elektronik dalam menawarkan produknya menghadapi tantangan seperti persaingan di antara penerbit uang elektronik, produk subtitusi dan harapan dari pemegang uang elektronik terhadap keamanan, kenyamanan dan kehandalan layanan (Kirana et al., 2017)

Perkembangan teknologi telah mendorong perilaku dan budaya masyarkat berubah khususnya terkait dalam bertransaksi keuangan yang lebih mudah dan praktis (Tribudhi \& Soekapdjo, 2019) hal ini sejalan dengan data yang ada. Bank Indonesia menyebutkan bahwa jumlah uang elektronik yang beredar hingga posisi September 2019 sudah mencapai 257.078.749 (Bank Indonesia, 2020a). Hal ini menunjukkan bahwa penggunaan uang elektronik atau non tunai oleh masyarakat Indonesia sudah sedemikian masif. Hasil penelitian sebelumnya terhadap 5 negara ASEAN, menjelaskan bahwa tren positif pada transaksi uang elektronik, 
perkembangan instrumen non tunai yang cepat dan beberapa faktor lain termasuk Indonesia, menunjukkan kesiapan masyarakatnya menuju ke masyarakat non tunai (cashless society) (Kartika \& Nugroho, 2015). Pengunaan uang elektronik untuk transaksi keuangan adalah suatu keniscayaan, masyarakat memanfaatkam uang elektronik karena beberapa pertimbangan seperti keamanan, manfaat dan kemudahan pengunaan (Nisa \& Rifaldi, 2017)

Penggunaan uang elektronik sudah menggantikan sebagian peran uang tunai hanya saja bila dilihat dari karakteristik uang, ada perbedaan yang mendasar antara uang elektronik dan uang tunai, misalkan uang elektronik tidak dapat dipertukarkan dengan uang elektronik yang lain. Oleh karena itu Bank Indonesia sebagai regulator, penerbit uang elektronik dan Dewan Syariah Nasional MUI perlu memperhatikan hal ini karena dalam pandangan syariat Islam, perbedaan karakteristik tersebut menyebabkan perbedaan hukum yang berlaku. Dalam hal ini lembaga-lembaga tersebut harus melindungi kepentingan pengguna khususnya masyarakat muslim karena Indonesia sebagai negara dengan jumlah penduduk Indonesia yang beragama Islam mencapai 207.176.162 jiwa atau berkisar 87,18\% dari jumlah penduduk Indonesia (Badan Pusat Statistik, 2011).

Di sisi lain, persaingan bisnis di antara penerbit uang elektronik semakin ketat, jumlah penerbit uang elektronik semakin banyak baik perbankan atau Lembaga Selain Bank (LSB) (Bank Indonesia, 2014). Saat ini Bank Indonesia telah mengizinkan beberapa bank dan LSB untuk menerbitkan uang elektronik atau lebih dari 39 perusahaan yang telah memiliki izin untuk menerbitkan uang elektronik. Volume uang elektronik yang ditransaksikan, meningkat terus yaitu mencapai 5.226.699.919 hingga bulan Desember 2019. Demikian halnya dengan nilai uang elektronik yang ditransaksikan, hingga bulan Desember 2019 telah ditransaksikan sebesar 145,165 Triliun Rupiah ("Uang Elektronik - Bank Sentral Indonesia,” 2020). Tabel 1 menunjukkan Penerbit Uang Elekronik yang diberikan izin oleh Bank Indonesia sebagaimana disajikan berikut ini.

Tabel 1. Penerbit uang elektronik

\begin{tabular}{llcl}
\hline No & \multicolumn{1}{c}{ Nama Penerbit } & No & \multicolumn{1}{c}{ Nama Penerbit } \\
\hline 1 & BPD DKI Jakarta & 21 & PT. Telekomunikasi Indonesia \\
2 & BPD Sumsel Babel & 22 & PT. Telekomunikasi Seluler \\
3 & Bank Central Asia & 23 & PT. Wit Ami Tunai Mandiri \\
4 & Bank CIMB Niaga & 24 & PT. XL Axiata \\
5 & Bank Mandiri & 25 & PT. Buana Media Teknologi \\
6 & Bank Mega & 26 & PT. Bimasakti Multi Sinergi \\
7 & Bank National Nobu & 27 & PT. Visionet Internasional \\
8 & Bank Negara Indonesia & 28 & PT. Inti Dunia Sukses \\
9 & Bank Permata & 29 & PT. Veritra Sentosa Internasional \\
10 & Bank QNB Indonesia & 30 & PT. Solusi Pasti Indonesia \\
11 & Bank Rakyat Indonesia & 31 & PT. Ezee Link Indonesia \\
12 & Bank Sinarmas & 32 & PT. Bluepay Digital Indonesia \\
13 & PT. Artajasa Pembayaran Elektronis & 33 & PT. E2pay Global Utama \\
14 & PT. Dompet Anak Bangsa & 34 & PT. Cakra Ultima Sejahtera \\
15 & PT. Espay Debit Indonesia Koe & 35 & PT. Airpay Internasional Indonesia \\
16 & PT. Finnet & 36 & Pt. Transaksi Artha Gemilang \\
17 & PT. Indosat & 37 & PT. Fintek Karya Nusantara \\
18 & PT. Nusa Satu Inti Artha & 38 & PT. Max Interactive Technologies \\
19 & PT. Skye Sab Indonesia & 39 & PT. Sarana Pactindo \\
20 & PT. Smart Telecom & & \\
\hline
\end{tabular}

Sumber : Bank Indonesia. Statistik Sistem Pembayaran, 2019 
Data Bank Sentral (Bank Indonesia, 2020b) pada Diagram 1, jumlah uang elektronik yang beredar hingga Februari 2020 menunjukkan tren yang meningkat dari tahun ke tahun.

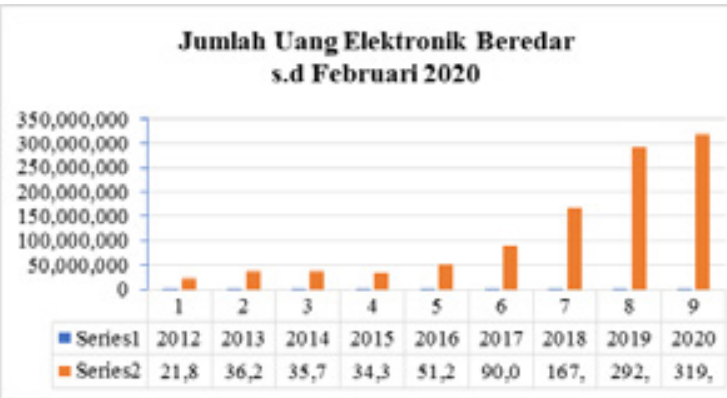

Gambar 1. Jumlah uang elektronik beredar

Sumber : Bank Indonesia. Statistik Sistem Pembayaran, 2020

Data Bank Sentral (Bank Indonesia, 2020a) pada Diagram 2 menunjukkan tren pertumbuhan volume transaksi yang menggunakan uang elektronik pada periode tahun 2011 hingga bulan Desember 2019. Penggunaan uang elektronik oleh masyarakat meningkat dari tahun ke tahun.

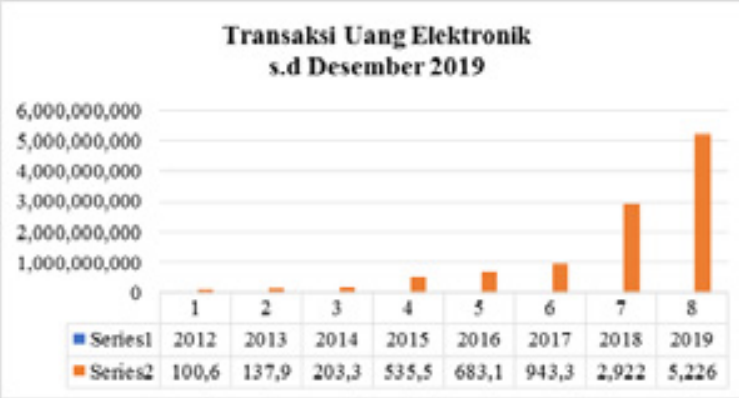

Gambar 2. Transaksi uang elektronik Sumber : Bank Indonesia. Statistik Sistem Pembayaran, 2020

Volume uang elektronik yang ditransaksikan, meningkat terus yaitu mencapai 5.226.699.919 hingga bulan Desember 2019.

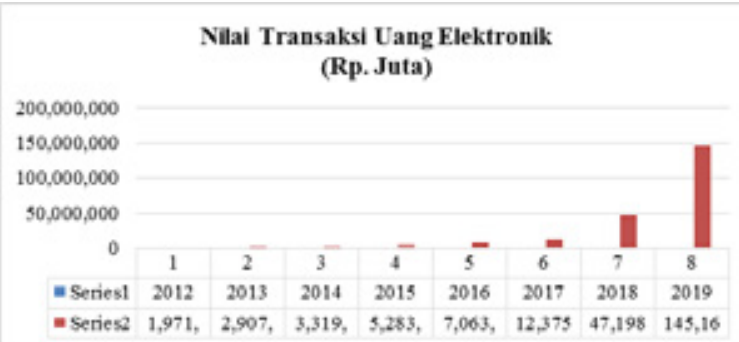

Gambar 3. Jumlah transaksi uang elektronik (triliun rupiah)

Sumber : Bank Indonesia. Statistik Sistem Pembayaran, 2020
Demikian halnya dengan nilai uang elektronik yang ditransaksikan, hingga bulan Desember 2019 telah ditransaksikan sebesar 145,165 Triliun Rupiah ("Uang Elektronik - Bank Sentral Indonesia," 2020).

Saat ini ada beberapa pendapat ahli dalam bidang muamalah syariah yang menyebutkan bahwa penggunaan uang elektronik sebagai alat pembayaran belum selaras dengan Al Quran dan Sunnah, sebagaimana pembahasan mengenai uang elektronik yang disampaikan oleh beberapa ahli Muamalah Syariah seperti Dr. Firanda Andirja, MA yang menerangkan bahwa ada 4 pendapat mengenai hukum/akad dari Go-pay dan yang paling tepat akad Qard (Firanda, 2019). Dalam penjelasannya Dr. Erwandi Tarmizi, MA, juga menerangkan bahwa uang elektronik akan menjadi riba apabila digunakan untuk membeli sesuatu dan mendapatkan diskon dari transaksi tersebut (Erwandi, 2020). Pendapat lainnya adalah mengatakan bahwa transaksi dengan uang elektronik adalah sama dengan transaksi dengan uang kartal dan hukum uang elektronik halal (Choiril, 2018). Dalam penelitiannya, Nur Rizki menyebutkan bahwa saat ini hanya ada 1 uang elektronik yang dinyatakan halal oleh Majelis Ulama Indonesia (Rizki, 2020). Pendapat lain mengatakan bahwa uang elektronik seperti Gopay dan Ovo dapat dikatakan menggunakan akad Sharf (Wijaya, 2018). Dari berbagai penjelasan tersebut, para ahli memiliki pandangan yang berbeda terkait dengan kesyariahan uang elektronik dan hal ini tentu berdampak pada masyarakat luas khususnya yang peduli dengan kesyariahan uang elektronik.

Penelitian ini akan mengulas beberapa hal yaitu bagaimana praktek dan pengelolaan uang elektronik di Indonesia, baik dilihat dari sisi regulator, penerbit dan pengguna uang elektronik? Mengapa pengelolaan uang elektronik baik yang menggunakan media chip microprocessor atau server base menimbulkan unsur yang menurut perspektif keuangan syariah belum tepat ? Penelitian akan menganalisis terhadap ketentuan dan praktek yang diterapkan oleh regulator maupun penerbit uang elektronik. Untuk masalah yang terkait Fiqih uang elektronik, peneliti 
menyerahkan penjelasannya kepada para ahlinya. Sehubungan dengan hal-hal di atas, maka penelitian ini dilakukan, dengan tujuan untuk melihat secara lebih detil pengelolaan uang elektronik ditinjau dari perspektif keuangan syariah. Penelitian ini dimulai dari penelusuran mekanisme pengelolaan uang elektronik oleh penerbit baik uang elektronik baik yang menggunakan chip microprocessor atau server base. Rujukan yang dipakai dalam penelitian ini adalah standar syariah yang diterbitkan oleh organisasi Accounting and Auditing Organization for Islamic Financial Institution (AAOIFI) yang berpusat di Bahrain dan Fatwa-fatwa Dewan Syariah Nasional MUI dan ulama sedunia yang tergabung di Majma' al-Fiqh al-Islami di bawah Liga Muslim Dunia.

\section{METODE}

Pada metode studi kasus di bisnis, ada 3 kegiatan yang relevan untuk menghimpun data yaitu interview, observasi dan analisis dokumen (Rahim \& Daud, 2015). Dalam penelitian ini, kegiatan yang dilakukan untuk mendapatkan informasi antara lain; observasi terhadap penggunaan uang elektronik baik uang elektronik yang menggunakan chip microprocessor dan server base yang menjadi obyek penelitian.

Analisis dokumen terhadap berbagai sumber data dan informasi seperti: dokumen mengenai peraturan dan ketentuan terkait uang elektronik yang diterbitkan oleh Bank Indonesia, European Central Bank, International Monetary Fund, Bank for International Settlements, Accounting and Auditing Organization for Islamic Financial Institution. Dokumen berupa fatwa-fatwa yang menyangkut uang elektronik dan simpanan di bank yang dikeluarkan oleh Dewan Syariah Nasional - MUI dan fatwa dari ahli fiqih dunia.

Dokumen-dokumen yang merupakan panduan, petunjuk atau spesifikasimengenai uang elektronik dikeluarkan oleh penerbit uang elektronik dalam hal ini adalah Bank BCA dan Go-Pay. Dokumen berupa hasil penelitian sebelumnya mengenai penggunaan uang elektronik, yang dilakukan oleh peneliti di tingkat Pasca Sarjana yang berbentuk thesis atau jurnal-jurnal baik dari dalam negeri maupun luar negeri. Dokumen berupa berita terkait dengan uang elektronik yang dibuat oleh media masa terpercaya. Dokumen berupa video atau tulisan dari para ahli muamalah syariah menyangkut penggunaan uang elektronik.

Desain Penelitian; Penelitian ini menggunakan metode penelitian kualitatif karena penelitian bertujuan untuk mendapatkan jawaban atas suatu pertanyaan, mengumpulkan bukti-bukti, dan mendapatkan temuan-temuan yang sebelumnya belum pernah dibahas. Pembahasan mengenai uang elektronik sudah dilakukan oleh beberapa pihak khususnya para ahli keuangan syariah namun pembahasan yang dilakukan dari aspek yang berbeda dengan penelitian ini. Penelitian ini menyangkut aspek perbankan, syariah dan bisnis yang merupakan masuk dalam ranah bidang studi ekonomi dan bisnis.

Gejala atau fenomena yang muncul di masyarakat adalah keresahan pengguna uang elektronik khususnya kaum muslimin di Indonesia terkait dengan perbedaan pendapat di antara para ahli keuangan syariah di Indonesia antara yang setuju dan tidak terkait dengan kebijakan Bank Indonesia mengenai pengelolaan uang elektronik. Metode penelitian kualitatif dipilih untuk mengulas hal tersebut karena penelitian ini terkait gejala atau fenomena khususnya dalam bidang sosial, hukum dan humaniora (Rahardjo, 2011).

Pendekatan studi kasus karena yang menjadi objek penelitian adalah sesuatu yang nyata dan mengemuka saat ini yaitu penggunaan uang elektronik sebagai pengganti uang kertas, di mana pembahasannya tidak hanya terkait dengan uang elektronik itu sendiri, namun terkait pengelolaan dana dari penerbitan uang elektronik dan tinjauannya dari para ahli muamalah syariah dan praktisi keuangan syariah. Penelitian ini akan memfokuskan pada 2 jenis uang elektronik yang saat ini dikenal luas dan untuk itu digunakan metode studi kasus. Mudjia Rahardjo dalam tulisannyamenyebutkan bahwa metode studi kasus merupakan tahapan penelitian yang dilakukan secara rinci mengenai suatu peristiwa yang aktual dan saat ini masih berlangsung (Rahardjo, 2017). Demikian juga dengan pendapat Marlisa Abdul Rahim yang menerangkan bahwa studi kasus 
merupakan suatu pembahasan mengenai sesuatu yang menarik atau unik dan terkait dengan individu, organisasi, program, proses manajemen dan suatu kejadian (Rahim \& Daud, 2015).

Pertimbangan lain sehingga studi kasus dipergunakan sebagai metode penelitian untuk membahas uang elektronik adalah dikarenakan ada 3 kondisi yang perlu diperhatikan dalam menentukan suatu metode penelitian antara lain adalah pertama; jenis pertanyaan penelitian atau "research question", kedua; seberapa besar peneliti dapat mengontrol terhadap peristiwa yang terjadi, ketiga; apakah keadaan tersebut "kontemporer" atau merupakan peristiwa masa lampau (Gray, 2014). Metode studi kasus dipilih karena dengan metode ini, gejala atau fenomena yang terjadi didalami sehingga dapat diketahui "How" dan "Why" mengenai penggunaan uang elektronik dari perspektif keuangan syariah.

Pelaksanaan Penelitian; Mudjia menyebutkan bahwa langkah awal dalam penelitian studi kasus adalah pemilihan topik yang merupakan body of knowledge dari bidang yang digeluti (Rahardjo, 2017). Dalam hal ini, pemilihan topik ini didasarkan pada dua hal yaitu pertama; bidang yang diminati dan dikuasai peneliti, kedua; hasil pengamatan peneliti yaitu kombinasi antara pengalaman ybs. selama ini sebagai praktisi di bidang manajemen dan perbankan konvensional dan syariah selama 17 tahun. Peneliti juga memiliki pengalaman sebagai pengguna uang elektronik baik yang menggunakan chip microprocessor dan server base, juga sumber informasi lainnya seperti hasil studi literatur/publikasi dan hasil mengikuti pertemuan ilmiah.

Pengumpulan Data; Proses penghimpunan data adalah untuk memastikan data terhimpun secara sistematis, dan tersusun sebagai database serta memungkinkan diakses dengan mudah. Studi kasus harus mempresentasikan data yang digunakan agar peneliti lain atau pihak yang berkepentingan dapat mereview data yang dipakai. Ketika peneliti lain dapat mengevaluasi data yang digunakan maka hal ini akan meningkatkan kehandalan studi kasus tersebut (Gray, 2014).

Penelitian ini ditujukan untuk kedua jenis uang elektronik yang menggunakan chip microprocessor dan server base, untuk memudahkan dalam proses penghimpunan data dan informasi maka dari kedua jenis uang elektronik tersebut masing-masing dipilih salah satu sample. Sebagaimana dilansir oleh kontan bahwa uang elektronik yang diterbitkan oleh Bank BCA atau BCA flazz mencapai sebanyak 14 Juta kartu atau uang elektronik yang menggunakan chip microprocessor (Walfajri, 2019). Sedangkan untuk uang elektronik yang yang menggunakan server base, saat ini adalah uang elektronik Gopay (Franedya, 2019). Oleh karena itu, BCA Flazz dan Go-pay dipilih menjadi obyek penelitian mengenai uang elektronik. Go-pay merupakan uang elektronik yang pertama kali digunakan sebagai alat pembayaran.

\section{HASIL}

Sebagai alat pembayaran, pembahasan mengenai uang elektronik meliputi banyak aspek baik secara teknologi, ekonomi \& bisnis, syariah, hukum dan kemanfaatan untuk masyarakat khususnya kaum muslimin. Perkembangan komputer dan teknologi informasi mendorong penggunaan uang elektronik oleh masyarakat dan hal ini berdampak luas tidak hanya terkait dengan bisnis namun juga secara moneter, sistem pembayaran serta kehidupan sosial dan budaya masyarakat.

Penelitian ini melihat keberadaan uang elektronik dari berbagai tinjauan. Dari aspek perkembangan teknologi dan internet terhadap industri keuangan, saat ini dikenal 2 jenis uang elektronik. Card-based products; dikenal sebagai kartu prepaid dan digunakan untuk pembayaran dengan cara tatap muka dengan nilai transaksi yang kecil serta dipakai pada vending machine. Nilai uang disimpan dalam chip microprocessor yang ditanam dalam kartu plastik. Kartu prepaid ini sebagai pelengkap dan bukan pengganti instrumen pembayaran ritel tradisional. Networkbased or software-based products. Dikenal sebagai uang kas digital, yang menggunakan perangkat lunak khusus pada komputer pribadi, uang dalam bentuk elektronik akan ditransfer melalui jaringan telekomunikasi dan Internet. Nilai uang yang dimiliki oleh pengguna, disimpan 
secara terpusat di server, dibawah kendali penerbit uang elektronik dan pengguna mengakses uang elektronik tersebut dari jarak jauh.

Seiring dengan perkembangan teknologi internet, masyarakat semakin mudah dalam menggunakan internet atau handphone untuk berbisnis atau jual beli secara online, hal ini ditandainya dengan tumbuhnya perusahaanperusahaan start up seperti Go-jek dan Grab, selain menawarakan jasa layanan transportasi online juga menawarkan beragam produk atau jasa lainnya seperti kuliner, kesehatan, barang kelontong dsb. Penggunaan uang elektronik meningkat karena layanan uang elektronik menjadi pendukung bisnis perusahaan transportasi online seperti Grab-pay untuk Grabike dan Gopay untuk Gojek (Tazkiyyaturrohmah, 2018).

Dari aspek ekonomi; penelitian mengenai pengaruh penggunaan uang elektronik terhadap stabilitas sistem keuangan di Indonesia menunjukkan bahwa penggunaan uang elektronik berpengaruh positif dan signifikan terhadap indikator M1 atau uang beredar (uang kartal, uang giral dan pembayaran non tunai), berpengaruh negatif terhadap indikator suku bunga dan tidak berpengaruh terhadap perputaran uang dan tingkat inflasi. Secara umum, penggunaan uang elektronik oleh masyarakat berpengaruh terhadap stabilitas moneter meskipun tidak langsung (Lintangsari et al., 2018).

Dari aspek sistem keuangan dan bisnis; ketentuan Bank Sentral Eropa No. EBC/2008/32 mengenai Laporan Keuangan untuk lembaga keuangan, menyebutkan bahwa transaksi dengan menggunakan uang elektronik dicatatkan pada sisi liabilitas, dalam kelompok simpanan overnight, termasuk dalam simpanan yang dapat dipindahtangankan (transferable deposit) (Europeon Central bank, 2016). Disamping itu, untuk bisa dikatakan sebagai uang elektronik, suatu alat pembayaran harus memiliki sifat "daya beli" (purchasing power) dan dikelompokkan sebagai simpanan dari pada mata uang (Apergis et al., 2020).

Usman dalam penelitiannya menyebutkan bahwa uang elektronik cocok untuk transaksi bisnis yang bernilai kecil, sebagai upaya pemenuhan terhadap instrumen pembayaran mikro dan menjadi sarana pembayaran yang cepat, berbiaya murah dan uang elektronik digunakan sebagai alat pembayaran giral layaknya uang tunai namun dilakukan secara elektronik (Usman, 2017). Masyarakat menggunakan uang elektronik karena kemudahan dan kepraktisannya khususnya untuk pembelanjaan ritel.

Dari aspek sosial dan budaya; penggunaan uang elektronik telah merubah budaya masyarakat untuk tidak lagi menggunakan uang tunai khususnya untuk transaksi-transaksi yang bernilai kecil dan ritel. Masyarakat memilih untuk menggunakan uang elektronik dalam bertransaksi dikarenakan beberapa faktor seperti gaya hidup, program promosi, kebutuhan, kemudahan dan penggunaannya yang mudah. Hasil penelitian yang dilakukan sebelumnya menunjukkan bahwa penggunaan yang mudah menjadi alasan utama masyarakat menggunakan uang elektronik (Surtikanti \& Mustofa, 2019). Hal ini juga didukung oleh penelitian terhadap mahasiswa Universtas Brawijaya yang hasilnya adalah faktor manfaat dan kepercayaan menjadi faktor yang berpengaruh dalam penggunaan uang elektronik di lingkungan mahasiswa Universitas Brawijaya (Adiyanti \& Pudjihardjo, 2014)

Dari aspek penyelenggara atau penerbit uang elektronik; berbagai aspek yang disebutkan di atas, telah mendorong tumbuhnya industri Layanan Keuangan Digital. Berdasarkan data Bank Indonesia, pihak yang menyediakan Layanan Keuangan Digital baik bank maupun bukan bank saat ini telah ada sebanyak 39 perusahaan atau Lembaga Selain Bank (LSB) (Indonesia, 2020). Perusahaan-perusahaan tersebut menerbitkan uang elektronik dengan berbagai jenis baik dalam media chip microprocessor atau server base.

Dari aspek regulator; untuk melindungi kepentingan masyarakat sebagai pengguna, mengelola risiko yang mungkin terjadi dan menjaga agar prinsip persaingan usaha terpenuhi dalam penyelenggaraan Layanan Keuangan Digital, Bank Indonesia mengeluarkan Peraturan Bank Indonesia nomor 20/6/PBI/2018 mengenai uang elektronik (Bank Indonesia, 2018).

Alat Pembayaran dan Sistem Transfer; uang 
elektronik merupakan alat pembayaran yang memiliki ketentuan: penerbit akan menerbitkan uang elektronik menurut nilai uang yang disetorkan ke penerbit; penyimpanan nilai uang di media server atau chip dan dalam bentuk elektronik, digunakan untuk alat pembayaran kepada pedagang yang bukan penerbit uang elektronik dan penerbit akan mengelola uang elektronik bukan dalam bentuk simpanan. Risiko uang elektronik bila hilang seperti uang tunai, dapat digunakan oleh orang lain dan tidak dapat diklaim dan dapat terdebet $2 \mathrm{x}$ pada mesin reader pada satu transaksi bila pengguna menempelkan $2 \mathrm{x}$.

Ketentuan Penyelenggaraan Layanan Keuangan Digital (LKD); untuk kepentingan transaksi pembayaran dan atau transfer dana, nilai uang elektronik dapat dipindahkan. Layanan Keuangan Digital merupakan kegiatan layanan jasa sistem pembayaran dan keuangan yang dilaksanakan oleh Penerbit bekerja sama dengan pihak ketiga dan menggunakan teknologi berbasis mobile atau web. Identitas pengguna uang elektronik dicatat dengan cara: unregistered yaitu identitas pengguna tidak tercatat pada Penerbit; dan registered, yaitu identitas penggunanya dicatat pada Penerbit. Terkait beberapa larangan semisal penentuan saldo minimum nilai uang sebagai batas pengakhiran penggunaan uang elektronik, memblokir nilai uang, membebankan biaya pengakhiran serta menghapus nilai uang pada saat pengakhiran.

Sistem Pengelolaan Dana dan Akuntansi Uang Elektronik; Sistem Pengelolaan Dana meliputi beberapa ketentuan : penerbit mengelola nilai uang elektronik bukan merupakan simpanan dan harus mengelola Dana Float yang merupakan seluruh nilai uang hasil dari penerbitan dan/ atau pengisian ulang, yang menjadi kewajiban Penerbit kepada pengguna dan penyedia barang dan jasa. Penerbit hanya boleh menggunakan Dana Float untuk memenuhi kewajiban kepada Pengguna dan Penyedia Barang dan/atau Jasa, dan bukan untuk kepentingan lain. Penerbit menempatkan Dana Float pada dengan ketentuan : minimal 30\% pada kas atau giro untuk Penerbit yang merupakan bank dan maksimal $70 \%$ pada surat berharga atau instrumen keuangan yang diterbitkan oleh Pemerintah atau Bank Indonesia atau rekening di Bank Indonesia

Tata Kelola Keuangan; Peraturan Bank Indonesia ini mengatur bahwa Penerbit mengelola nilai uang elektronik bukan sebagai simpanan, di mana pencatatan dana dari penerbitan uang elektronik tidak sama dengan pencatatan rekening simpanan seperti tabungan, giro, deposito atau rekening nominatif. Akun Dana Float di posting pada pos kewajiban segera atau rupa-rupa pasiva dan bukan pos Dana Pihak Ketiga.

Dari aspek bisnis, pembahasan berikutnya adalah terkait dengan petunjuk penggunaan dari uang elektronik yang diterbitkan oleh BCA Flazz dan Go-pay. Peneliti memilih kedua jenis uang elektronik tersebut dikarenakan keduanya dikenal baik oleh masyarakat dan kedua-nya memiliki media penyimpanan dan pencatatan data indentitas pengguna yang berbeda. BCA Flazz merupakan contoh uang elektronik yang menggunakan media chip microprocessor sebagai penyimpan nilai uang dan data pengguna tidak tercatat (unregistered) serta Go-pay adalah contoh uang elektronik yang menggunakan media server base sebagai sarana penyimpan nilai uang dan data pengguna tercatat (registered).

BCA Flazz; menurut petunjuk penggunaan uang elektronik yang dibuat oleh Penerbit dalam hal ini adalah Bank BCA disebutkan bahwa Kartu Flazz merupakan alat pembayaran berbentuk kartu yang dipakai untuk membayar pembelian barang dan/atau jasa melalui pendebitan dana yang tersimpan di dalam Kartu Flazz. Pemegang kartu dapat memindahkan tangankan kartu ini kepada pihak lain dan dalam penggunaannya tidak dibutuhk Personal Identification Number (PIN) maupun tanda tangan. Bila Kartu Flazz dicuri atau hilang, penerbit, dalam hal ini, Bank BCA tidak dapat memblokir dana yang pada Kartu Flazz tersebut dan hal ini menjadi tanggung jawab Pemegang Kartu sepenuhnya dan Kartu ini dapat dipergunakan selama nilai uang pada kartu tersebut mencukupi. Dana yang tersimpan di Kartu Flazz tidak dijamin oleh Lembaga Penjamin Simpanan (LPS) karena bukan merupakan simpanan. Secara tegas disebutkan pada petunjuk penggunaan bahwa Kartu Flazz 
bukan merupakan simpanan (BCA - Flazz, 2020). Kartu Flazz merupakan salah satu uang elektronik yang diterbitkan oleh Bank (buku IV)

Go-Pay; merupakan salah satu uang elektronik yang menurut istilah yang disebutkan dalam Peraturan Bank Indonesia, diterbitkan oleh Lembaga Selaian Bank. Menurut petunjuk penggunaan uang elektronik Go-pay dijelaskan beberapa hal penting antara lain; penerbit Go-Pay hanya akan menggunakan saldo uang elektronik untuk memenuhi kewajiban kepada pemilik uang elektronik dan merchant, artinya penerbit Go-Pay tidak bisa menggunakan uang elektronik untuk hal lainnya. Penerbit Go-Pay mengatur jumlah saldo pada akun sebagai berikut; bila tidak terverifikasi maka jumlah saldo akun Go-Pay dibatasi sebesar Rp. 1.000.000,- dan bila terverifikasi maka jumlah saldo akun Go-Pay dibatasi sebesar Rp. 10.000.000,- atau jumlah saldo lainnya yang lebih kecil. Jumlah transaksi uang yang masuk setiap bulan ke akun Go-Pay dibatasi maksimal Rp. 20.000.000,-

Penerbit Go-Pay bukan bank sehingga saldo akun Go-Pay bukan merupakan tabungan, tidak termasuk sebagai produk yang dilindungi oleh Lembaga Penjamin Simpanan dan pemilik uang elektronik tidak mendapatkan fitur seperti pada rekening bank misalkan bunga dsb. Pertunjuk penggunaan uang elektronik Go-Pay juga menegaskan bahwa uang elektronik Go-Pay bukan merupakan produk simpanan (Gojek, 2020)

Ketentuan menurut Syariah Islam merujuk pada Fatwa Dewan Syariah Nasional-MUI; DSN-MUI memiliki kewenangan untuk membuat fatwa-fatwa yang bertujuan untuk melindungi kepentingan/kemashlahatan bagi umat muslim di Indonesia, termasuk yang harus ditetapkan adalah fatwa untuk menggunakan uang elektronik. Fatwa-fatwa DSN-MUI sudah menjadi bagian dari ketetapan hukum karena dijadikan rujukan dalam pembuatan berbagai peraturan dan atau ketentuan oleh Bank Indonesia, Otoritas Jasa Keuangan khususnya dalam bidang keuangan dan perbankan. Fatwa DSN-MUI Nomor 116 tahun 2017 yang mengatur 2 jenis akad yang dapat dipakai antara Penerbit dan pemegang uang elektronik, akad tersebut adalah wadi'ah atau qardh.

Secara rinci; bila akad wadi'ah yang dipakai, maka berlaku ketentuan antara lain nilai uang pada uang elektronik yang dititipkan pada Penerbit atas izin pemilik uang elektronik akan mengubah akad wadi' ah menjadi akad qardh, dan oleh karena itu tanggung jawab yang diemban oleh penerima titipan seperti tanggung jawab dalam yang diemban pada akad qardh. Bila akad qardh, maka berlaku ketentuan antara lain; Nilai uang pada uang elektronik merupakan hutang, sehingga dapat diambil atau digunakan oleh pemilik uang elektronik setiap saat. Penerbit uang elektronik boleh menginvestasikan uang dari pemegang uang tersebut. Dalam hal ini, penerbit wajib mengembalikan jumlah pokok piutang Pemegang uang elektronik kapan saja sesuai kesepakatan; Penerbit dapat menggunakan (menginvestasikan) uang hutang dari pemegang uang elektronik.

Rujukan lainnya adalah syariah standar berdasarkan Accounting and Auditing Organization for Islamic Financial Institution (AAOIFI). Syariah standar AAOIFI; No. 40 mengenai Distribusi Profit; penggunaan rekening giro terlarang karena merupakan pinjaman kepada bank di mana harus menjamin pengembalian dana dan memberikan imbalan kepada nasabah. No. 21 mengenai Financial Paper; pengunaan instrumen keuangan atau surat berharga seperti obligasi terlarang, bila di dalamnya ada penetapan imbal hasil dari dana yang dipinjam atau kelebihan dalam bentuk apapun. Khalid dalam tulisannya menyebutkan bahwa Majma' al-Fiqh al-Islami di bawah Liga Muslim Dunia dalam keputusannya No. 86, 3/9 mengenai simpanan bahwa dari sudut pandang fiqih, simpanan bank, baik di bank syariah atupun bank konvensional merupakan hutang (Kholid, 2012). Bank mengikatkan diri untuk mengembalikan dana yang senilai, saat pemilik dana meminta dananya. Maka status simpanan seperti ini merupakan bentuk pinjaman (qard atau salaf). Demikian Wahbah dalam bukunya menerangkan bahwa bila bank menerima dana dan bank boleh memanfaatkan dan menginvestasikan dana tersebut dalam bisnis maka kedudukan 
akadnya adalah qard atau pinjaman (Wahbah, 2011). Mufti dalam penelitianya menyebutkan bahwa pemilik yang mengizinkan dananya untuk dikelola oleh bank mengakibatkan perubahan status dana tersebut menjadi pinjaman (qard), hal ini sejalan dengan pendapat ulama Empat mahzab bahwa qard adalah dana tersebut dipakai dan dijamin (Mufty, 2014). Terkait dengan riba atau adanya tambahan atas pengembalian pinjaman 1) Allah Ta'ala mengharamkan praktek riba; "Allah telah menghalalkan jual beli dan mengharamkan riba." (Al Baqarah: 275) 2) Allah memerintahkan orang-orang beriman untuk menghentikan praktik riba sebagaimana ayat "Hai orang-orang yang beriman, bertakwalah kepadaAllah dan tinggalkan sisa riba (yang beIum dipungut) jika kamu orangorang yang beriman" (Al Baqarah 278), 3) Allah Ta'ala mengancam akan memerangi orangorang yang tidak menuruti perintah-Nya untuk meninggalkan riba, sebagaimana ayat "Maka jika kamu tidak mengerjakan (meninggalkan sisa riba), maka ketahuilah, bahwa Allah dan RasulNya akan memerangimu." (QS Al Baqarah 279). 4) Dan Allah berjanji akan memasukkan pelaku riba ke dalam neraka kekal selamanya.

\section{PEMBAHASAN}

Berdasarkan analisis terhadap ketentuan syariah yang merupakan I'jma para fuquha dan regulasi yang dikeluarkan oleh Bank Indonesia, European Central Bank, International Monetary Fund, Bank for International Settlements, Accounting and Auditing Organization for Islamic Financial Institution dan Dewan Syariah Nasional - MUI serta penggunaan uang elektronik sehari-hari, didapat beberapa hal yang perlu mendapatkan perhatian baik dari regulator, penerbit uang elektronik dan pengguna uang elektronik.

Pembahasan akan dilihat dari beberapa hal yaitu mengenai pengertian atau konsep tentang uang; sebagaimana dijelaskan sbb. International Monetary Fund dalam salah satu publikasinya menyebutkan bahwa uang memiliki fungsi sebagai alat tukar, satuan hitung dan penyimpan nilai kekayaan (Asmundson \& Oner, 2012). Sebagai alat tukar uang berfungsi sebagai sesuatu yang dapat digunakan orang untuk membeli dan menjual satu sama lain. Undang-Undang pemerintah Singapura No. 2 tahun 2019 mengenai Jasa Pembayaran, menjelaskan bahwa salah satu fungsi uang adalah alat tukar yang diterima oleh publik, atau bagian dari publik, sebagai pembayaran untuk barang atau jasa atau untuk pelunasan hutang (Payment Services Act 2019, 2019) Mohsin dan Mehra dalam "Time Value of Money in Islamic Perspective and the Practice in Islamic Banking Implications" meneliti bahwa dari perspektif Islam, uang adalah salah satunya berguna sebagai alat tukar (Nurrachmi et al., 2012).

Pembahasan terkait dengan uang elektronik yaitu uang elektronik baik yang menggunakan chip microprocessor dan server base belum dapat memenuhi kriteria mengenai uang. Hal ini bisa dibuktikan dari beberapa hal yaitu uang elektronik hanya bisa digunakan pada ekosistem keuangan dan bisnis tertentu saja, Go-pay sebagai uang elektronik yang diterbitkan untuk mendukung bisnis Gojek tidak bisa dipakai untuk pembayaran tol atau tiket KRL dan MRT. Demikian BCA Flazz juga tidak bisa digunakan untuk dipakai untuk membeli makanan yang ditawarkan pada aplikasi Gofood. Bila dianalogikan dengan uang kartal yang bisa dipertukarkan, uang elektronik tidak bisa ditransfer di antara penerbit uang elektronik. Uang elektronik pada BCA Flazz belum bisa ditransfer ke uang elektronik Go-pay dsb.

Pengelolaan Uang Elektronik, secara konsep dijelaskan bahwa ketentuan Bank Sentral Eropa No. EBC/2008/32 mengenai Laporan Keuangan untuk lembaga keuangan, menyebutkan bahwa transaksi dengan menggunakan uang elektronik dicatatkan pada sisi liabilitas, dalam kelompok simpanan overnight, termasuk dalam simpanan yang dapat dipindahtangankan (transferable deposit) (Europeon Central bank, 2016). Artinya bahwa uang elektronik dikelompokkan sebagai aset dari lembaga pengelola uang elektronik tsb. Demikian dengan peraturan Bank Indonesia nomor 20/6/PBI/2018 mengenai uang elektronik (Bank Indonesia, 2018) menyebutkan bahwa uang elektronik tidak masuk dalam kelompok simpanan/dana pihak ketiga melainkan di kewajiban segera atau rupa-rupa pasiva dan Dana float harus disimpan dalam bentuk minimal 
$30 \%$ (tiga puluh persen) ditempatkan pada kas (bagi Penerbit berupa bank umum berdasarkan kegiatan usaha (BUKU) 4 : Bank Mandiri, Bank BRI, Bank BCA, Bank BNI dsb.), atau pada giro di Bank yang merupakan BUKU 4 (bagi penerbit lainnya seperti Go-pay, Ovo dsb.), dan maksimal $70 \%$ di tempatkan dalam bentuk surat berharga/ instrumen keuangan yang diterbitkan oleh Bank Indonesia/pemerintah.

Pembahasan terkait hal tersebut adalah sebagai berikut pertama; kebijakan Bank Indonesia yang mengharuskan, penerbit uang elektronik harus menempatkan pada rekening giro (khusus penerbit yang bukan bank), dan di tempatkan dalam bentuk surat berharga/instrumen keuangan mamenunjukkan bahwa penerbit uang elektronik akan mendapatkan jasa giro atau imbal hasil dari penempatan dana float tersebut atau dengan kata lain dari tinjauan fiqih dana tersebut merupakan simpanan atau implementasi dari akad qard namun mendapatkan tambahan dari nilai pokoknya. Kedua, dana masyarakat yang disimpan di uang elektronik baik dalam bentuk registered maupun unregistered juga merupakan simpanan. Majma' al-Fiqh al-Islami di bawah Liga Muslim Dunia dalam keputusannya No. 86, 3/9 menerangkan bahwa "simpanan bank, baik di bank Islam maupun bank konvensional, dari sudut pandang fiqih merupakan hutang atau qard, standar syariah nomor 21 dan 40 dari AAOIFI dan Fatwa DSN MUI No. 116 mengenai uang elektronik menerangkan bahwa implikasi dari kedua hal di atas, penerbit uang elektronik menempatkan dananya pada instrumen keuangan/ investasi yang tidak sejalan dengan firman Allah Ta a'la sebagaimana telah disebutkan di bagian sebelumnya dan demikian pemegang uang elektronik, menurut tinjauan fiqih, uang elektronik tersebut merupakan simpanan atau merupakan hutang dan oleh karena itu setiap pemberian diskon oleh penerbit uang elektronik menjadi riba.

\section{SIMPULAN}

Berdasarkan pembahasan di atas dapat disimpulkan bahwa pengelolaan uang elektronik di Indonesia belum selaras dengan prinsip syariah karena dana floating adalah simpanan yang merupakan penerapan dari akad qard yang tidak diperbolehkan mendapatkan pengembalian lebih karena merupakan riba. Hal ini telah dilarang dan diterangkan dengan jelas pada ayat-ayat $\mathrm{Al}$ Quran. Bank Indonesia sebagai regulator perlu mencari instrumen lainnya yang sesuai dengan prinsip syariah agar di satu sisi kepentingan kaum muslimin dapat terlindungi namun di sisi lain masyarakat dapat memanfaatkan kemajuan teknologi dalam melakukan transaksi keuangan sehari-hari. Bank Indonesia dan DSN MUI dapat berkoordinasi dalam menentukan instrumen yang tepat semisal menempatkan dana float pada instrumen yang tidak mengandung riba. Kaum muslimin perlu mendorong agar regulator dapat menyiapkan penggantinya sehingga kaum muslimin tetap bisa bertransaksi ritel dengan memanfaatkan uang elektronik.

\section{PENGHARGAAN}

Pada kesempatan kali ini penulis ingin mengucapkan terimakasih kepada semua yang terlibat baik secara langsung maupun tidak langsung yang tidak bisa penulis sebutkan satu persatu. Terimakasih atas saran, masukan, dan bantuan, semoga penelitian ini bisa bermanfaat bagi semua pihak.

\section{DAFTAR PUSTAKA}

Adiyanti, A. I., \& Pudjihardjo, M. (2014). Pengaruh Pendapatan, Manfaat, Kemudahan Penggunaan, Daya Tarik Promosi, dan Kepercayaan terhadap minat menggunakan layanan E-Money. In Jurnal Ilmiah Mahasiswa FEB (Vol. 3, Issue 1). https://jimfeb.ub.ac.id/ index.php/jimfeb/article/view/1590/1456

Apergis, N., Kunitsyna, N., \& Dyudikova, E. (2020). The role of electronic money in the payment system: Evidence from middleincome economies. International Journal of Emerging Trends in Engineering Research, 8(1), 67-78. https://doi.org/10.30534/ ijeter/2020/12812020

Asmundson, I., \& Oner, C. (2012). Back to Basics: What Is Money? - Finance \& Development, September 2012. International Monetary Fund (IMF). https://www.imf.org/external/pubs/ft/ 
fandd/2012/09/basics.htm

Bank Indonesia. (2018). Peraturan Bank Indonesia Nomor 20/6/PBI/2018. Bank Indonesia. https://www.bi.go.id/id/peraturan/ sistem-pembayaran/Pages/PBI-200618.aspx

BCA - Flazz. (2020). Bank BCA. https://www. bca.co.id/flazz

Candraditya, H. (2013). Analisis Penggunaan Uang Elektronik (Studi Kasus Pada Mahasiswa Pengguna Produk Flazz BCA di Fakultas Ekonomika dan Bisnis Universitas Diponegoro) | Candraditya | Diponegoro Journal of Management. Diponegoro Journal of Management, 2(3). https://ejournal3.undip. ac.id/index.php/djom/article/view/3210

Choiril, A. (2018). E-money (Uang Elektronik) dalam Perspektif Hukum Syari'ah. Jurnal Qawanin, 2(1), 95-112.

Erwandi, T. (2020). Uang Elektronik (e-money). https://www.youtube.com/ watch? $=$ P9zzHKDaDw8

Europeon Central bank. (2016). concerning the balance sheet of the monetary financial institutions sector. Official Journal of the European Union, 79(3), 34-40. https:// eur-lex.europa.eu/legal-content/EN/ TXT/?uri=celex:32009R0025

Firanda, A. (2019). Hukum GO PAY, Pendapat yang Lebih Kuat. https://www.youtube.com/ watch? $\mathrm{v}=\mathrm{dGK}$ wgiGBb9g

Franedya, R. (2019). Terungkap! Transaksi GoPay di 2018 Tembus Rp 87 T. Https:// Www.Cnbcindonesia.Com/. https://www. cnbcindonesia.com/tech/2019021110312537-54742/terungkap-transaksi-gopay-di2018-tembus-rp-87-t

Gojek. (2020). Cara Top Up GoPay (Isi Saldo) via Driver, Alfamart, Bank. Gojek. https:// www.gojek.com/gopay/kebijakan-privasi/

Gray, D. E. (2014). Chapter 11 Designing Case Studies in Doing Research in the Real World. In Designing Case Studies in Doing Research in the Real World (3rd ed.). Sage Publications Inc. https://www.academia. edu/29965288/Chapter_11_Designing_Case_ Studies_in_Doing_Research_in_the_Real World_2014_3rd_edition_London_Sage
Indonesia, B. (2020). Penyelenggara Uang Elektronik - Bank Sentral Republik Indonesia. https://www.bi.go.id/id/statistik/sistempembayaran/uang-elektronik/Contents/ Penyelenggara Uang Elektronik.aspx

Kholid, S. (2012). No Title. Pengusaha Muslim. https://pengusahamuslim.com/5895tabungan-di-bank-syariah-bukan-wadiah.html

Kirana, W., Putu, W. H., \& Iik, W. (2017). Tantangan dan Hambatan Implementasi Uang Elektronik di Indonesia: Studi Kasus PT XYZ. Jurnal Sistem Informasi, 13(1), 38-48. https://jsi.cs.ui.ac.id/ index.php/jsi/article/ view/465/343

Lintangsari, N. N., Hidayati, N., Purnamasari, Y., Carolina, H., \& Ramadhan, W. F. (2018). Analisis Pengaruh Instrumen Pembayaran Non-tunai Terhadap Stabilitas Sistem Keuangan di Indonesia. Jurnal Dinamika Ekonomi Pembangunan, 1(1), 47. https://doi. org/10.14710/jdep.1.1.47-62

Mufty, A. (2014). Tabungan: Implementasi Akad Wadi'ah atau Qard? (Kajian Praktik Wadi'ah di Perbankan Indonesia). Jurnal Hukum Islam (JHI), 12(2). http://e-journal.iainpekalongan. ac.id/ index.php/jhi/article/view/556

Nisa, S., \& Rifaldi, W. G. R. (2017). Peta Positioning Uang Elektronik Berdasarkan Persepsi Masyarakat di Indonesia Tahun 2017. Jurnal Riset Bisnis Dan Manajemen, 10(2), 34-41.

Nurrachmi, R., Fathia, M., Mad-ahdin, A., Radenarmad, N., \& Akhtar, R. (2012). Time Value of Money in Islamic Perspective and the Practice in Islamic Banking Implications. MPRA.

Payment Services Act 2019. (2019). Singapore Statutes Online. https://sso.agc.gov.sg/Act/ PSA2019/Uncommenced/20190405142502? DocDate $=20190220$

Rahardjo, M. (2011). Metode pengumpulan data penelitian kualitatif.

Rahardjo, M.(2017). Studi Kasus Dalam Penelitian Kualitatif : Konsep dan Prosedurnya. http:// repository.uin-malang.ac.id/1104/

Rahim, M. A., \& Daud, W. N. W. (2015). The Case Study Method in Business. Scholars Journal 
of Arts, Humanities and Social Sciences, 3, 105-109.

Rizki, F. N. (2020). Analisis Kesesuaian Syariah Electronic Money pada Bank Penerbit Uang Elektronik di Indonesia. An-Nisbah: Jurnal Ekonomi Syariah, 7(1), 212-249.

Singgih, P. (2016). Pengaruh Persepsi Manfaat, Persepsi Kemudahan Penggunaan, dan Persepsi Risiko terhadap Minat Menggunakan Layanan Uang Elektronik (Studi Kasus pada Masyarakat di Kota Semarang) | Priambodo | Jurnal Ilmu Administrasi Bisnis. Jurnal Ilmu Administrasi Bisnis, 5(2), 127-135. https:// ejournal3.undip.ac.id/index.php/jiab/article/ view/11294

Surtikanti, \& Mustofa, R. H. (2019). Utilization of Electronic Money. IOP Conference Series: Materials Science and Engineering, 662(2). https://doi.org/10.1088/1757$899 X / 662 / 2 / 022013$

Tazkiyyaturrohmah, R. (2018). Eksistensi Uang Elektronik Sebagai Alat Transaksi Keuangan Modern. Muslim Heritage, 3(1), 23. https:// doi.org/10.21154/muslimheritage.v3i1.1240

Tribudhi, D. A., \& Soekapdjo, S. (2019). Determinasi transaksi dengan menggunakan uang elektronik di Indonesia. KINERJA, 16(1), 78-84. http://journal.feb.unmul.ac.id/ index.php/KINERJA/article/view/5218

Usman, R. (2017). Karakteristik Uang Elektronik Dalam Sistem Pembayaran. Yuridika, 32(1), 134-166. https://www.e-journal.unair.ac.id/ YDK/article/view/4431

Wahbah, A.-Z. (2011). Fiqih Islam Wa Adillatuhu (10th ed.). Gema Insani.

Walfajri, M. (2019). BCA: Uang elektronik berbasis kartu unggul pada kecepatan transaksi. Kontan.Co.Id. https://keuangan.kontan.co.id/ news/bca-uang-elektronik-berbasis-kartuunggul-pada-kecepatan-transaksi

Wijaya, H. (2018). Takyīf Fiqh Pembayaran Jasa Transportasi Online Menggunakan Uang Elektronik (Go-Pay dan OVO). Nukhbatul 'Ulum, 4(2), 125-148. https://doi. org/10.36701/nukhbah.v4i2.46 